\title{
HOPE AND THE UNCERTAIN FUTURE
}

We hope for things we believe will bring us something good like well-being or joy or happiness. Hope involves optimism: when I hope for something, I believe, at least to some extent, that the thing I hope for can be realized. Moreover, my thinking about the object of hope will raise in me joy or some other positive feeling, and I therefore desire the object to come true. For example, I hope that future generations will hear skylarks singing in Finland: thought about skylarks' surviving causes joy in me, I desire it, and I believe it is possible. I also hope for peace in Middle-East: thinking peace there delights me, therefore I desire peace, and I believe attaining peace is not beyond reach.

On the other hand, hope involves something quite contrary to joy. I cannot be sure that the thing I hope for will prove to be true, for something quite opposite to it may happen. Hope involves uncertainty, and fear that something else will happen that causes sadness and pain. As Spinoza defined in his Ethics:

Hope (spes) is an inconstant joy, born of the idea of a future or past thing whose outcome we to some extent doubt (Spinoza, Ethics, part IV, definition XII of the affects).

Fear and uncertainty are due to insufficient knowledge. I don't know what will happen with larks or with Palestinians. Not well, I am afraid. Approximately 40000 species of living beings are disappearing every year from the globe, and local populations are destroyed much more in number and much more rapidly: roughly 1800 per hour. For instance in England such birds as skylarks and barn swallows, very common earlier everywhere in the country, are becoming rare. Their fate in Finland will likely be similar, for the biological development seems to go to the same direction as in other western count- ries. If I were sure that nothing would threaten skylarks, my fear would disappear and only joy left. But this would mean that I no longer hope for survival. I am confident of it. "There is neither hope without fear, nor fear without hope," Spinoza says.

On the other hand, if I were sure that skylarks will disappear anyway whatever I try to do, my hope will change to joyless despair. According to Spinoza, despair is "sadness born of the idea of a future or past thing, concerning which the cause of doubting has been removed" (Ethics, definition XV of the affects).

The heavy conflicts in Middle-East make me very pessimistic about the future of Palestinians or Syrians, close to despair. The strength of hope depends on how deep our doubts concerning the desired outcomes are.

2. Experiences of uncertainty and doubt about the future are particularly common during critical periods in history. Right now we have such period. There are good reasons for a feeling of uncertainty: the uncontrolled growth of world population, great and unpredictable ecological crises like the climate change and the biggest wave of extinction in the whole world history, vast economic crises with increasing unemployment, unstable political and social organizations, rapidly growing migrations of people, and violent conflicts in various part of the world. These are frightening things. They involve great risks and threats.

On the other hand, technology is making enormous progress, and much hopeful expectations are directed to it. It seems that almost all problems are thought to become solved by means of the new technology. Is this justified? Does the increasingly technological way of life give us reason to optimism 
concerning the future? Does it bring us joy? I think some doubt is appropriate.

It is of course true that practically any development involves good and bad sides, raises hope and despair, causes joy and sadness. With respect to hope, I speak of three different kind of sectors in the present development, naming them 'white', 'grey' and 'black' ones.

By the white sector I mean things that are useful for good and proper living. Certainly the new technology promotes economy and standard of living of people, increasing thereby also social security. Information and communication technology opens new possibilities for world-wide communication between people and stimulates creative activities.

3. However, everything in the developing information society is not 'white' in this sense. We come to the grey sector when we consider undesirable and harmful consequences of things which as such are good and desirable. Increasing lack of joy and concern makes the living grey, and some symptoms of this kind of development are already in sight. I refer to such things as social interactions becoming 'technologized', that is, getting more and more mediated by technical devices, and commercialized when information is mainly used to manipulate people's consumption behavior. The important thing to be noted is that technology not only produces means to us but that technical devices themselves become the reality we live in. We begin to exercise more interaction with machines than with our fellow beings. The modern itc-technology creates virtual reality that is for many people much more appealing than life outside machines and networks. Some years ago I read in Helsingin Sanomat (the leading newspaper in Finland), 'Millions of people will permanently move to virtual reality, researchers predict.' It is now true.

It has been said that a typical neurosis in the present information society is the fear of intimacy: technology in a way estranges us of close and warm relations with other persons. But because a lone and isolated life it is not good, either, then playing com- puter games and surfing in internet provide a suitable solution.

Herbert Marcuse, well-known as a philosopher and social critic, expressed some decades ago his worries about the influence of mass media to the young generation. He noticed that the educational tasks of mother and father are shifting to mass media, especially to entertainment industry. The educational role of home and school will be diminished. The most alarming thing is that appeals to the affective part of our personality are strongly increasing in mass media. According to Marcuse, this is apt to cause disturbances in the proper development of the self or ego of children and their personal identity. Interest in active and demanding thinking will decrease, he prophesized, and a passive, indifferent, joyless and even self-destructive attitude to life will be developed. On the other hand, the distorted mental energy may break forth as aggressive and destructive conduct.

The grey sector also involves different kind of risks creating uncertainty. When social structures are rapidly changing, uncertainty and insecurity will take place and life becomes emotionally complicated. At the same time privatization, moving to one's own world and lack of concern about others are growing. This kind of development is essentially related to the 'instrumentalization' of our life as described above.

4. Even more gloomy things can be seen. In the black sector of development the darkest powers of humankind become released entirely unchecked. Such happens with the collapse of political and social structures, as witnessed by what is now going on in Iraq and Syria. Within the Western world, spreading of political and religious terrorism, international criminality, drug business, traffic in human flesh and political corruption are extending like an explosion. In the illegal transfer of labor power from one country to another, the amount of money moving yearly is ca 15 billion dollars. By means of the new technology, criminal global trade is able to make present political and social structures obsolete or entirely helpless, and controlling international criminality becomes ex- 
tremely difficult. It is estimated that the western states are able to control just roughly three per cent of the illegal business.

In short, the new information and communication technology effectively helps all kind of dark forces. The internet provides almost anything from instructions for nuclear weapons to sadistic shows and child pornography. Because the content of the internet is practically beyond all control and interference, our lowest level of impulses are recklessly made use of.

5. These courses of development remind in a startling way of social developments in Athens some 2400 years ago. We know how Socrates and Plato severely blamed Athenian leaders of moral corruption. They said aloud what was commonly known: that the main aim of politicians was to gather as much profit as possible to be able to live easy and comfortable life. This became a common aim for people. In the Republic Plato wrote, how an Athenian man 'lives, always surrendering rule over himself to whichever desire comes along, as if it were chosen by lot; and when that is satisfied, he surrenders the rule to another, not disdaining any but satisfying them all equally' (561b). Easy life and unrestricted freedom were the ideals of every citizen:

And so he lives on yielding day by day to the desire at hand. Sometimes he drinks heavily while listening to the flute; at other times, he drinks only water and is on a diet; sometimes he goes in for physical training; at other times, he's idle and neglects everything; and sometimes he even occupies himself with what he takes to be philosophy. He often engages in politics, leaping up from his seat and saying and doing whatever comes into his mind. If he happens to admire soldiers, he's carried in that direction, if money-makers, in that one. There's neither order nor necessity in his life, but he calls it pleasant, free, and blessedly happy, and he follows it for as long as he lives. (Republic 561d)

This looks like a post-modern life in the ancient Athens!
Plato wanted to say that this kind of life, that is, life free in an uncontrolled way, indicates lack of right order in the soul. People have no control of their behavior; they are unable to put order into their values. The sense of justice has disappeared, Plato says. 'Isn't it shameful when someone not only spends a good part of his life in court defending himself or prosecuting someone else but, through inexperience of what is fine, is persuaded to take pride in being clever at doing injustice and then exploiting every loophole and trick to escape conviction' (Republic 405bc). Also the ideals of education loose their signifycance when the 'utmost freedom' sets aside all selfcontrol and respect for others.

Plato saw that with increasing material wellbeing superfluous needs easily get the central role. Shifting from the white sector to the grey one will take place. His real point, however, was even more profound. He realized the danger of moving gradually to the dark sector. When the moral control gets looser and egoistic desires for comfort begin to occupy minds, people will be driven towards a totally unchecked life. They will go weary with ordinary pleasures and seek for more vehement experiences, until they are gradually moved into totally uninhibited perversions typical of insane tyrants. Plato reminds of how 'there is a dangerous, wild, and lawless form of desire in everyone, even in those of us who seem to be entirely moderate or measured' (Republic 572b). Without self-control such desires easily get loose. When this kind of black development finds room in a society, a total political and social breakdown will be close, Plato warned. And this, indeed, was the fate of the Athenian state shortly after Plato's death.

What about our western civilization? Are we in the same situation now? How strong is the black sector, and is there a danger of its growing stronger that the white one? Because we cannot be sure about the future, this or that way, we can just hope or fear. What is the basis of our hope here and elsewhere? 
6. Let us turn back to Spinoza's definition of hope. According to it, hope is inconstant joy, and joy is defined as follows:

Joy (laetitia) is man's transition from a state of less perfection to a state of greater perfection. (Ethics, part 3, definition 2 of the affects).

The opposite emotion of sadness is defined correspondingly as a transition from a state of greater perfection to one of less perfection.

What is involved in these definitions? Let us think that all what we call physical or material reality, all phenomena in the physical world, consist ultimately of one basic power. At present, the physical theory knows four basic forces, but efforts are made to find a way of unifying them into just one basic force (the Theory of Everything). Let us further think that also the organic nature consists of the same power, that is, that all growth and development is due to this power. The power is expressed as vitality, as a kind of inner activity of organisms.

Suppose last that the essence of human beings consists of the same power as inorganic and organic things. As material beings we are composed of elementary particles and their motions, and as organic beings we have vital energy that appears as growth, health and vigor in general. Most importantly, however, we have mental power, or power of thinking, as Spinoza calls it.

Spinoza put forth the bold idea that just one basic kind of power exists. His 'theory of everything' was that there is just one substance, Deus sive natura, the essence of which consists of infinite power (Ethics, part 1, proposition 34). Whatever exists expresses 'in a certain and determined way' this power and is caused by it. In other words, this power controls the motions of material bodies, it expresses itself as the diversity of life forms in nature, and all mental activities are based on it. The remarkable thing here is that this power is active in the strong sense of causing other things but being itself without external cause; it is self-sustaining like life. It is this kind of active power or force that forms, according to Spinoza, the essence of reality. It is operating everywhere in nature, including the human world. In us it is working as an inner drive he calls conatus ('striving'). In other words, we are by nature active and vital beings.

According to this theory, our essence as active power is part of the active power of the whole universe or whole reality. Thus, the more a person has this power, the more perfect she is. Our perfection means level of vitality, energy of life, will of living. However, to what extent we are able to realize this energy in practice depends on the conditions we live in. The external things cause different kind of ideas in us, and each idea has a definite effect on our innate active power: they may increase or diminish it, or leave untouched. An increase is passing to a greater perfection and means joy, a decrease is passing to a lesser perfection and means sadness.

7. When Spinoza speaks of hope as inconstant joy, it means, first, that thinking of the thing hoped for causes joy in us, that is, increases our vital power and thereby our will of living. Secondly, it means that besides the idea of the object of hope we have also ideas of things which may prevent this object to be realized. These ideas cause in us fear, an inconstant sadness. Hope is never pure joy but is always associated with fear.

Anyway, hope as joy means an increase in active power and is thus an expression of growing love of life. Hope increases optimism; we feel us strong to the extent we have hope. But only to that extent, says Spinoza, for hope is always associated with uncertainty and doubt about what will happen. One might think that hope, according to Spinoza's conception, would be related to how much joy the idea of the thing hoped for will raise in us. This, however, it is not the case, for the joy is diminished by sadness caused by the idea of things preventing the object of hope to be realized. The fear of not obtaining the desired thing will always be present with hope. When the belief in the desired outcome is strong, and doubt slight, then fear vanishes and hope grows high. 
The ultimate basis of our hope is thus provided by our beliefs concerning future outcomes. Now, our beliefs are more or less subjective. We may feed high hope by unrealistical beliefs, like believing that the leaders of ISIS or Syria or Israel will soon offer hand of peace, or that the new technology will only be for white purposes in the furture. Such hope is based on wishful thinking or self-deception, and it may be of help in maintaining optimism in gloomy days of life. I think, however, that the only sustainable basis for hope in the long run is provided by well-established beliefs.

Unfortunately, the most frightening cases like crises in Middle-East and Ukraine or climate change

\section{REFERENCES}

1. Marcuse, H. (1989). "The Obsolescence of the Freudian Concept of Man". In Critical Theory and Society, edited by S. E. Bronner and D. MacKay Kellner. London: Routledge.

2. Pietarinen, J. and Viljanen, V. (2009). The World as Active Power. Studies in the History of European Reason. Leiden: Brill. are very unpredictable, and finding even reasonable bases for our beliefs seems almost impossible. The key questions here are: What can I do for making desirable outcomes more probable? What can my country do? What can other countries do? International organizations? Religious leaders? What are the best means for furthering peace and nature preservation? Although it may seem extremely difficult to get reasonable answers to such questions, we have to form beliefs about these matters. Some reasons for our beliefs are better than others, and research will produce material to help in finding as good reasons as possible. I hope so.

3. Plato. (1997). Republic (translated by G. M. A. Grube). In Plato. Complete Works, edited by J. M. Cooper. Indianapolis: Hackett.

4. Spinoza, B. (1994). The Ethics (translated by E. Curley). In A Spinoza Reader, edited by $E$. Curley. Princeton: Princeton University Press.

PIETARINEN JUHANI

\section{HOPE AND THE UNCERTAIN FUTURE}

\section{SUMMARY}

Benedict Spinoza defined hope as an inconstant joy - inconstant, because hope involves uncertainty and doubt. Hope means optimism mixed with pessimistic feelings. For Spinoza, hope amounts to an increase in our inherent active power, in our vitality or love of life, but because of being associated with fear, hope also involves something which is apt to re- duce this power. Our beliefs concerning future outcomes are crucial here. They form the ultimate basis of our hope.

Key concepts: hope, fear, uncertainty, active power, Spinoza, Plato. 


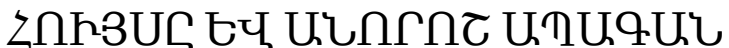

\section{UUФПФПధU}

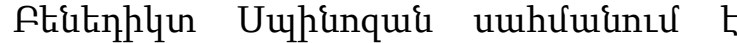

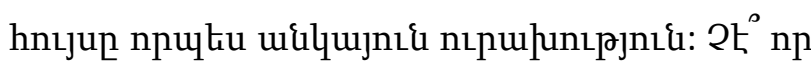

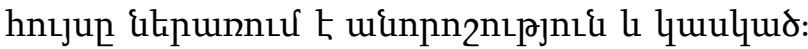

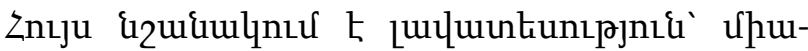

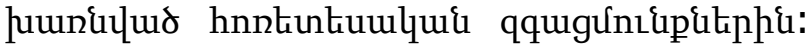

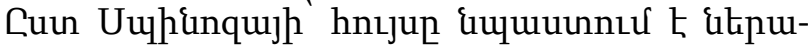

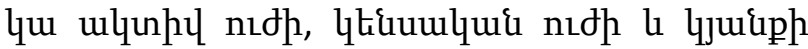

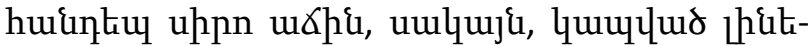

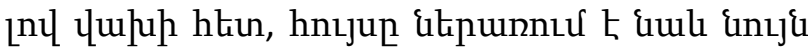

ujn nıdn Euluqtiginn unupp: Uuququjnıu

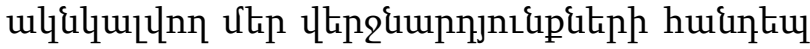
hurluung uju hupgntu tulquis ptenulquinu-

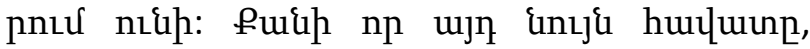

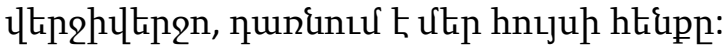

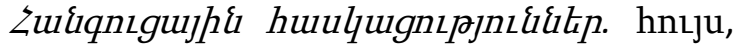

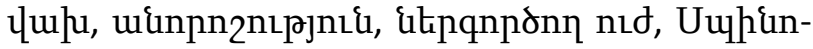
qu, Tluunnis:

ПИЕТАРИНЕН ЮХАНИ

\section{НАДЕЖДА И НЕОПРЕДЕЛЁННОЕ БУДУЩЕЕ}

\section{PEЗЮME}

Бенедикт Спиноза определил надежду как непостоянную радость, так как надежда включает в себя неопределённость и сомнение. Надежда означает оптимизм, смешанный с пессимистическими нотками. Согласно Спинозе, надежда способствует росту активности наших врождённых сил, жизнестойкости и жизнелюбия, однако в виду того, что всё это ассоцириуется с чувством стра- ха, надежда всегда включает в себя нечто, способное ослабить эти силы. Наши убеждения касательно будущего исхода событий здесь имеют решающее значение. Они образуют главную основу нашей надежды.

Ключевые понятия: надежда, страх, неопределённсть, активная сила, Спиноза, Платон. 